\title{
Кіберспорт як соціально-спортивне явище в умовах сучасного розвитку інфформаційного суспільства
}

\section{Євгеній Імас}

Національний університет фрізичного виховання і спорту України, Київ, Україна

Анотація. Існування електронного спорту як соціального фееномену і його динамічний розвиток на сьогодні ставлять ряд актуальних питань, серед яких варто виділити необхідність правового регулювання, профрілактику захворювань, формування рухової активності гравців, роботу з подолання адиктивної поведінки (якщо це має місце), створення раціональної системи підготовки і змагань кіберспортсменів. Мета. На основі методологічного і філософського підходів розглянути кіберспорт як соціальне явище, виявити його характерн риси для формування стійких відносин в інсрормаційному просторі. Методи. Аналіз і синтез, порівняння, систематизація, узагальнення. Результати. Кіберспорт - унікальне соціальноспортивне явище, що розвивається за своїми законами. Він безпосередньо пов'язаний $з$ різними сфрерами людської діяльності, має свої специфічні риси, що дозволяють розглядати його як самостійний динамічний напрям. Стан і розвиток кіберспорту в сучасному суспільстві свідчить, що він міцно зайняв свої позиції серед безлічі сфрер діяльності людини. Ключові слова: кіберспорт, кіберспортсмени, віртуальні ігри.

\section{Ievhenii Imas}

\section{E-SPORTS AS A SOCIO-SPORTS PHENOMENON IN THE MODERN DEVELOPMENT OF THE INFORMATION SOCIETY}

Abstract. The existence of e-sports as a social phenomenon and its dynamic development today raises a number of pressing issues, including the need for legal regulation, disease prevention, the formation of active motor activity of players, work to overcome addictive behavior (if any), creation of a rational training system and e-sports competitions. Objective. Based on methodological and philosophical approaches to consider e-sports as a social phenomenon, to identify its characteristics for the formation of stable relations in the information space. Methods. Analysis and synthesis, comparison, systematization, generalization. Results. E-sports is a unique social and sports phenomenon that develops according to its own laws. It is directly related to various spheres of human activity, has its own specific features that allow considering it as an independent dynamic direction. The state and development of e-sports in modern society shows that it has firmly taken its place among many areas of human activity.

Keywords: e-sports, esports players, virtual games.
Постановка проблеми. Відповідно до класичної етимології поняття «спорт» (старофрр. desport - гра, розвага) у повсякденному житті - це діяльність, якій притаманні змагальність, захоплення й азарт, що вимагає максимального напруження для досягнення результату на певному етапі вдосконалення. Фізична культура і спорт впливають не лише на біологічну сфреру людини, а й на інтелектуальну, емоційну і духовну $[4,6]$.

Феномен спортивної діяльності як складне соціо-культурне, фрілософське й економічне явище еволюціонував разом із розвитком людства, видозмінюючись і вдосконалюючись відповідно до запитів суспільства, враховуючи його життєві і духовні прояви. Сучасні тенденції спорту глобалізація, комерціалізація, поява нових технічно складних видів спорту, великі обсяги фрізичних і психоемоційних навантажень, що обмежують працездатність і ресурси організму спортсменів, комп'ютерні технології - наприкінці XX ст. визначили появу потенційних напрямів розвитку сфрери спорту.

Інформатизація всіх ссрер людської діяльності і повсякденного життя, що є одним із вражаючих феноменів останньої чверті XX ст., дозволила перемістити привабливість, азарт і сакральність спорту 3 арен масової реальної присутності у віртуальний інтернет-простір. Впровадження цифрових технологій у різні напрями і структурні елементи спорту знайшло абсолютно нове втілення в конвергенції фрізичного і віртуального світів, відомій нині як феномен комп'ютерного спорту, або кіберспорту [2, 16]. Видовищність і популярність онлайн-змагань не тільки не поступаються за своїм рівнем класичному спорту, а й 3 кожним роком зростають. Переконливим прикладом служить щорічна динаміка збільшення кількості гравців у різних кібердис-
Imas le. E-sports as a socio-sports phenomenon in the modern development of the information society. Theory and Methods of Physical education and sports. 2020; 4 : 13-17

DOI: 10.32652/tmfvs.2020.4.13-17
Імас $€$. Кіберспорт як соціальноспортивне явище в умовах сучасного розвитку інформаційного суспільства. Теорія і методика фрізичного виховання і спорту. 2020; 4: 13-17

DOI: 10.32652/tmfvs.2020.4.13-17 
циплінах і одночасна участь у турнірі великої кількості геймерів (19 січня 2014 р. під час проведення онлайн турніру з дисципліни «World of Tanks» одночасно брали участь 1,114 млн користувачів) [15].

Комп'ютерний спорт як унікальне соціальне явище, створене завдяки стрімкому розвитку інформаційних і розважальних технологій, сьогодні не лише самостійна субкультура, а й невід'ємна складова спорту [10, 28], незважаючи на досі актуальні дискусії з приводу його належності до цього виду діяльності людей. Феномен електронного спорту з моменту свого зародження залишається предметом гострих дискусій серед представників різних соціальних груп - від підлітків, які грають у мережеві ігри, до «світил» світової науки

Популяризація, розширення географрії кіберспорту і кількості гравців, підвищення видовищності індустрії відеоігор у сучасному світі сприяли її перетворенню в потужну галузь економіки з обігом понад 80 млрд доларів, а ринок комп'ютерних ігор за прибутками обійшов індустрію кінопрокату ще в 2013 р. [14]. Внаслідок зростаючої ролі комп'ютерного спорту в масовій культурі й економіці ігрова комп'ютерна індустрія поступово проникає в суміжний бізнес, а також вирішує маркетингові завдання інших компаній [26]. Серії масових турнірів із великим призовим фондом, якісне фрінансове забезпечення та перспективні зарплати не тільки для спортсменів, а й для команди супроводу (тренерів, психологів, менеджерів, технічного персоналу) сприяють зростанню привабливості кіберспорту і зацікавленості в ньому великої кількості людей. Необхідно визнати, що комп'ютерний спорт перестав бути просто розвагою. Індустрія кіберспорту набирає обертів, уже сьогодні за популярністю і фрінансовою складовою випереджаючи ряд традиційних видів спорту [5].

На сучасному етапі розвитку людства явище кіберспорту розвивається масштабно, охоплюючи різні верстви населення. Особливий поштовх кіберспорт отримав в умовах обмеження можливості для населення різних країн займатися руховою активністю на спортивних майданчиках, у тренувальних залах, спортивних клубах і фрітнес-центрах, викликаних пандемією Covid-19. 3 іншого боку, відсутність необхідності здійснювати off-line подорожі і можливість брати участь у віртуальних змаганнях дозволяють зменшити експлуатацію природних ресурсів, які постійно виснажуються. Останнє є важливою екологічною складовою спорту. Слід розуміти, що заняття деякими видами спорту, залежними від наявності природних ресурсів планети (наприклад, гольф) незабаром можуть стати неможли вими без впровадження технологічних рішень [24]. Відтак гостро актуалізується питання неминучості еволюційної трансфформації класичних видів спорту в електронний аналог.

Однією з актуальних проблем сучасного кіберспорту є відсутність законодавчої бази і правового регулювання питань, що виникають у ход його розвитку. Необхідно зазначити, що на сьогодні у правовій системі цілого ряду країн відсутні десініції понять кіберспорт, комп'ютерна гра учасник турніру або чемпіон з кіберспорту, а також інших термінів, які супроводжують цю категорію суспільних відносин [2]. Відсутність належного правового регулювання даної ссрери створює потенційну небезпеку для учасників відносин у сфрері кіберспорту, породжує можливість для численних правопорушень і зловжи вань 3 боку агентів щодо учасників організаторів електронних змагань.

Крім того, значущим питанням після офріційного визнання кіберспорту видом спорту стало застосування допінгу. Залишається невизначеним розуміння, які саме речовини і фрармакологічні препарати є забороненими для кіберспортсменів. Це питання досить важливе, оскільки в історії кіберспорту вже існує прецедент, коли Кор «semphis» Фрісен (досить відомий гравець в Counter-Strike) в інтерв'ю заявив, що під час змагань вся його команда приймала аддеролл - психостимулюючий препарат на основ амфетаміну [2].

Невивченість френомену кіберспорту як сучасного спортивного спрямування залишається актуальною і обговорюється на всіх рівнях розвитку науки. Розгляд цього питання вимагає серйозного вивчення і проведення досліджень. У нашій статті ми зробили спробу проаналізувати сильні та слабкі сторони, притаманні кіберспорту як унікальному перспективному соціальному явищу.

Мета дослідження - на основі методологічного і фрілософського підходів розглянути кіберспорт як соціальне явище, виявити його характерні риси для формування стійких відносин в інформаційному просторі.

Методи дослідження: аналіз і синтез, порівняння, систематизація, узагальнення.

Результати дослідження та їх обговорення. Порівняльний аналіз традиційних видів спорту і кіберспорту виявив наявність спільних характерних рис - закономірностей і відмінностей. Підготовка в класичних видах спорту і в кіберспорті ґрунтується на загальних підходах, засобах і методах, в основі яких лежать використання змагальної діяльності і підготовки до неї, зіставлення й оцінка реалізації потенційних можливостей людини [15]. Ще однією спільною рисою є поступове і планомірне досягнення високого рівня майстерності на основі вдосконалення специфічних навичок, формування мотивації до перемоги, цілеспрямованості, підвищення самодисципліни і розвитку високої швидкості реакції, яка значно перевищує швидкість середньостатистичної людини $[1,23]$.

Як у комп'ютерному, так і в традиційних видах спорту результативність та успішність пов'язані з технікотактичною та психологічною підготовкою: здатністю стратегічно мислити, тактично грамотно діяти, умінням працювати в команді, приймати рішення в стресових ситуаціях, притаманних змагальній боротьбі, на основі швидкої оцінки потенційних можливостей суперника [27].

Популярність віртуальних ігор, що зростає з кожним роком, фрормування кіберспортивних команд із різних дисциплін, поява рейтингу провідних кіберспортсменів - усе це вимагає створення ефективної системи 
їх підготовки на різних рівнях, постійного вдосконалення фрізичних і інтелектуальних якостей і навичок. Тренування професійних кіберспортсменів триває в середньому 5-7 год на день, у гравців-початківців для досягнення професійного рівня обсяг тренувальної роботи становить понад 7 год на день [5].

В умовах підвищеної конкурентності особливе місце в підготовці кіберспортсменів займають формування та вдосконалення соціальних умінь, таких як неконфліктність, стресостійкість, нарівні з удосконаленням тонких рухових навичок і швидкості реакції. Ефективність удосконалення всіх згаданих «soft skills» вимагає ведення здорового способу життя [17].

Дискусія. Об'єктивний аналіз різноманітних проявів впливу кіберспорту на структуру і фрункції людського суспільства дає всі підстави стверджувати, що для кіберспорту, як і для будь-якої спортивної діяльності і традиційних видів спорту, характерні певні позитивні і негативні прояви. Розглянемо позитивний вплив кіберспорту на спортсменів і суспільство в цілому. Характеризуючи заняття кіберспортом, необхідно відмітити, що порівняно 3 іншими видами спорту, електронний спорт і безпосередньо віртуальні змагання є безпечними та нетравматичними.

Згідно з даними деяких фрахівців [5, 12, 22], під впливом регулярних електронних змагань сповільнюється вікове згасання розумових здібностей, удосконалюються самодисципліна і самоконтроль, розвиваються 30 рова пам'ять, тонке диференціювання дрібної моторики пальців тощо.

3 точки зору психофрізіологічних характеристик заняття кіберспортом сприяють розвитку логіки, дедукції, аналітичного, критичного, абстрактного, образного і нестандартного мислення, покращують здатність до прогнозування результату, підвищують концентрацію уваги.

Важливим $є$ також фракт істотного прикладного значення комп'ютерного спорту, оскільки у процесі цієї діяльності формуються спеціальні особистісні властивості кіберспортсменів: когнітивна гнучкість, висока швид- кість мислення, командна взаємодія в доповненій реальності, комп'ютерна грамотність. Вони виявляються необхідними і високо цінуються в багатьох інших галузях людської діяльності від економіки (економічні аналітики та системні адміністратори) до оборони (кібервійска, оператори безпілотників і роботів тощо) $[9,18]$. Таким чином, подальший розвиток кіберспорту сприяє удосконаленню специфічних навичок та якостей людиниоператора у високотехнологічних процесах і управлінні особливо складними системами, що, у свою чергу, вимагає розробки методик ефективної підготовки фахівців вузькопрофрільних напрямів [12].

Високий соціальний статус кіберспортсменів вимагає від них цілеспрямованої підготовки, виконання великих за обсягом та інтенсивністю тренувальних і змагальних навантажень, а також визначається високим рівнем фрізичного та психічного здоров'я як основи функціональної і психологічної підготовки, у тому числі і в екстремальних ситуаціях, якими, по суті, є змагання високого рівня. Спортивні досягнення кіберспортсменів $€$ істотним чинником формування мотивації молоді до системної роботи над собою $[18,25]$.

Зауважимо, що у ході змагальної діяльності у кіберспортсменів поліпшуються соціальні навички і якості взаєморозуміння, комунікабельність, вирішення загальних завдань і проблем, терпимість до помилок інших, розподіл обов'язків і відповідальності, командна робота $[3,21]$. У результаті цього вдосконалюється індивідуальна і групова діяльність людини в різних комбінаціях, краще проявляються набуті соціальні якості, що являють собою квінтесенцію людського досвіду $[5,11]$.

Слід зазначити, що змагання у комп'ютерному спорті, в основу яких покладені гуманістичні принципи чесної гри, фрормують здорове конкурентне середовище зі своїми морально-етичними нормами, виявляють обдарованих і успішних людей $[13,18]$. Прогресуюче інсрормаційне суспільство $€$ важливим компонентом адаптації підростаючого покоління до змін в соціальному середовищі. Молоді люди мають реальну можливість реалізувати свої інтелектуальні здібності та інформаційно-комунікативні навички в рамках змагальної діяльності $[13,18]$.

Незаперечним позитивним фрактом у заняттях комп'ютерним спортом $€$ безмежні можливості кіберспорту для різних верств населення і безпосередньо для категорії людей з обмеженими можливостями у фізичному здоров'ї, які можуть виступати на змаганнях нарівні зі здоровими людьми. Таким чином, змагальний процес і відповідна підготовка реалізуються у форматі інклюзивних спільнот [18].

Беручи до уваги те, що кіберспорт $€$ невід'ємною частиною сучасного суспільства, необхідно пам'ятати не лише про всі позитивні аспекти подальшого розвитку комп'ютерного спорту, а й враховувати всі потенційні негативні аспекти, які виникають через заняття комп'ютерними іграми.

Аналіз особливостей впливу кіберспорту на фізичне і психічне здоров'я людини розкриває перелік проблемних моментів, що потребують уваги і регулювання. До таких проблем фрахівці відносять тривале перебування перед монітором, занурення у віртуальну реальність, погіршення зору, порушення постави, патологічні зміни діяльності серцево-судинної, нервової, ендокринної та інших систем унаслідок зменшення рухової активності. Однак згадані проблеми можна вирішити досить просто - за допомогою гігієни праці та відпочинку під керівництвом професійних тренерів або фрахівців-медиків [5].

Безумовно, кіберспорт як вид діяльності людини досить специфічний, а медико-біологічних досліджень у цій сорері на сьогодні недостатньо. Проте поступово фрормується система знань за даними досліджень психіки кіберспортсменів і фрізіології їхньої спортивної діяльності. Надалі вона повинна стати основою для розробки системи спеціальної підготовки спортсменів до змагань, що дозволить розширити і правильно розуміти прикладний аспект комп'ютерного спорту. Інноваційні технології та інструментарій у вигляді апаратно-програмних додатків 
контролю здоров'я і фрізичної активності, електронні фрітнес-платфрорми, трекери, пульсометри та інші прилади надають досить широкі можливості для правильної організації тренувального процесу кіберспортсменів 3 урахуванням принципу індивідуалізації, складання раціональних програм харчування і розпорядку дня, контролю і моніторингу динаміки фуннціонального стану їхнього організму [8].

Одним 3 аргументів, висунутих опонентами проти занять кіберспортом, вважають кількість часу, який особа витрачає на комп'ютерні ігри і який вона могла б витратити на прогулянки, безпосереднє спілкування з друзями і більш високоінтелектуальні заняття (читання книг, відвідування театру тощо), а також різноманітні психологічні аспекти транссрормації особистості - стирання межі добра і зла через агресивний характер деяких ігор, фрормування емоційної нестабільності, залежність від комп'ютера $[2,11]$

Дійсно, з усім перерахованим важко сперечатися, але якщо спробувати розібратися в цьому питанні більш детально, то слід зупинитися на деяких фактах. У дослідженнях психологів зазначено, що віртуальна реальність викликає залежність лише у певної групи людей, які переживають серйозні психологічні проблеми в реальному житті [19].

Фахівцями було визначено основні критерії, що визначають наявність залежності від комп'ютерних ігор, серед яких повне небажання відволіктися від гри, відсутність здатності спланувати закінчення сеансу, сильне роздратування при вимушеному припиненні гри, уникання домашньої роботи й ігнорування службових обов'язків, зловживання психостимуляторами, зневажливе ставлення до свого здоров'я, відмова від особистої гігієни та сну на користь проведення якомога більшої кількості часу за комп'ютером [19].

Комп'ютерна залежність, так само як і алкогольна та наркотична, негативним чином позначається на психіці людини, що тягне за собою проблеми міжособистісного, соціокультурного характеру. Проте подолати подібну залежність можна, і в цьому особливе місце належить фрахівцям із психології та педагогіки, одним із завдань яких є пошук і розробка дієвих засобів і методів подолання деструктивних проявів адиктивної поведінки [22].

Слід також зазначити, що виникнення залежності від комп'ютерних ігор є крайнім проявом, невластивим для основної спільноти кіберспортсменів. Вона $€$ притаманною лише окремим індивідам, тож відсоток залежних людей серед кіберспортсменів незначний і не перевищує такий в інших сфрерах людської діяльності.

Висновки. Стан і розвиток кіберспорту в сучасному суспільстві свідчать про те, що він як соціальне явище і самостійний вид спорту міцно зайняв свою нішу серед безлічі сфрер діяльності людини.

Цьому процесу сприяють розвиток цифрових технологій, зміна культури користувачів, за рахунок яких удосконалюються всі складові кіберспорту, а також поступово змінюються загальнолюдські цінності й еволюціонує суспільний досвід [7, 20]. Сучасний світ змушений пристосовуватися до обмежень пересування внаслідок пандемії Covid-19, відвідування масових арен класичних видів спорту і неможливості відчувати емоції, отримувати враження в реальному часі. Ці обмеження можуть бути заповнені за рахунок комп'ютерних змагань.

Існування електронного спорту як соціального феномену і його подальший динамічний розвиток ставлять перед людством ряд актуальних питань, серед яких необхідність правового регулювання, профрілактика захворювань і застосування допінгу, формування раціональної рухової активності гравців різних вікових груп, робота з подолання (в окремих випадках) адиктивної поведінки, екологічн питання, створення раціональної системи підготовки і змагань кіберспортсменів.

Кіберспорту властиві і риси, які характерні для традиційних видів: наявність змагальної діяльності і підготовка до неї, планомірне досягнення високого рівня майстерності, формування мотивації, розвиток специфрічних фрізичних, психічних і психофрізіоло- гічних якостей спортсмена. При цьому кіберспорт $\epsilon$ унікальним соціальноспортивним явищем, який розвивається за своїми законами, безпосередньо пов'язаний із різними ссрерами людської діяльності, має свої специфічні риси, що дозволяють розглядати його як самостійний динамічний напрям.

Актуальні проблеми розвитку кіберспорту вимагають подальших ретельних і серйозних досліджень, систематизації і узагальнень.

Конфлікт інтересів. Автор заявляє, що відсутній будь-який конфлікт інтересів.

\section{ЛITEPATУPA}

1. Болдырева СП, Гришачев АС. Киберспорт. Вестник научных конференций. 2017;36(19):24-5

2. Буянова АВ, Козилина ВВ. Киберспорт: история становления, современное состояние и перспективы развития. Социальнополитические науки. 2017;5:77-80.

3. Быков НН. Киберспорт как средство повышения эффективности профессиональной подготовки студентов. Интеллектуальные ресурсы - региональному развитию. 2020;2:1236.

4. Завальнюк ОВ. Феномен спорту: від філософської теорії до сучасних практик. Київ: НПУ ім. М. П. Драгоманова; 2017. 384 с.

5. Исмаилов АА. Киберспорт как социальное явление. International Journal of Humanities and Natural Sciences. 2019;7-1:40-2

6. Імас $€ B$, Мічуда ЮП. Тенденції розвитку сфери фізичної культури та спорту в умовах сучасного ринку. Теорія і методика фріз. виховання і спорту. 2015;2:142-9.

7. Казакова ОА, Козьма НА. Киберспорт спорт будущего. Olymplus (гуманитарная версия). 2016;1(2):29-31.

8. Корчемная НВ. Профилактика профессиональных заболеваний киберспортсменов. Компьютерный спорт (киберспорт): проблемы и перспективы. Материалы III Всерос. научнопракт. конф., 16-20 декабря 2014 г. 2014;16-21.

9. Кравченко ВИ. Особенности трансформации «информационного» человека. Вестник ЛГУ им. А. С. Пушкина. 2012;1:114.

10. Кушнарева ИА, Стричко АВ. Киберспорт. Новая наука: опыт, традиции, инновации. 2015:1:31-2.

11. Майорова ЛВ. К вопросу развития стратегического мышления у юных спортсменов с помощью компьютерных игр. Компьютерный спорт (киберспорт): проблемы и перспективы. Материалы III Всерос. научно-практ. конф., 16-20 декабря 2014 г. 2014;22-6.

12. Мещеряков AB, Новоселов МА, Скаржинская ЕН. Активность регуляторных систем в компьютерных играх. Компьютерный спорт (киберспорт): проблемы и перспективы. Материалы III Всерос. научно-практ. конф., 16-20 декабря 2014 г. 2014;22-6.

13. Миронцов ИВ. Киберспорт как инструмент (ре)социализации. Журнал Белорусского государственного университета. Философия. Психология. 2019;2:62-7. 
14. Назарова ЕВ. Киберспорт и бизнес: обзор точек роста и сотрудничества. Компью терный спорт (киберспорт): проблемы и перспективы. Материалы III Всерос. научно-практ. конф., 16-20 декабря 2014 г. 2014;22-6.

15. Панкина ВB, Хадиева РТ. Киберспорт как феномен XXI века. Физическая культу ра. Спорт. Туризм. Двигательная рекреация. 2016;1(3):34-8.

16. Предовская ММ, Тебякина ЕЕ. Киберспорт - спортивная реальность нового мира Материалы итоговой научно-практ. конф. профессорско-преподавательского состава национального государственного университета физической культуры, спорта и здоровья им. П. Ф. Лесгафта. 2019;162-5

17. Семибратова АВ. Киберспорт как часть адаптивной физкультуры. Состояние и перспективы развития физической культуры, спорта и адаптивной физической культуры. Сб. статей по материалам Всерос. студенческой научнопракт. конф., 18 апреля 2019 г. 2019;79-82.

18. Скаржинская ЕН, Новоселов МА, Сурконт КВ. Компьютерный спорт (киберспорт) вид спорта? Компьютерный спорт (киберспорт): проблемы и перспективы. Материаль III Всерос. научно-практ. конф., 16-20 декабря 2014 г. 2014;69-74.

19. Соловьева ЕВ. Зависимость школьников от компьютерных игр. Компьютерный спорт (киберспорт): проблемы и перспективы. Материалы III Всерос. научно-практ. консф., 16-20 декабря 2014 г. 2014;80-3.

20. Трещева EE, Чеджемов ГА. Эпоха постмодерна. Общество виртуальной реальности Наука XXI века: актуальные направления развития. 2017;1(1):122-5

21. Cottrell C, Nicholas Mcmillen N, Harris BS. Sport psychology in a virtual world: Considerations for practitioners working in esports. Journal of Sport Psychology in Action. 2019;10(2):73-81. doi.org/10.1080/21520704.2018.1518280.

22. Hilvoorde IV, Pot N. Sport and Play in a Digital World Embodiment and fundamental moto skills in esports. Sport, Ethics and Philosophy. 2016;10(1):1-14.

23. Llorens MR. Esport gaming: the rise of a new sports practice. Sport, ethics and philosophy. 2017; 11(4):464-7. doi.org/10.1080/17511321.20 17.1318947.

24. Miah A. The cybersport nexus, in Billings, A. \& Hardin, M. The Routledge Handbook of Sport and New Media, Oxon \& New York, Routledge. 2014;76-86.

25. Pedraza-Ramirez I, Musculus L, Raab M Laborde S. Setting the scientific stage for esports psychology: a systematic review. International Review of Sport and Exercise Psychology. 2020;13(1):319-52. doi.org/10.1080/175098 $4 X .2020 .1723122$

26. Seo Y. Electronic sports: a new marketing landscape of the experience economy. Journal of marketing management. 2013;29(13-14):1542-60.

27. Jenny SE, Manning RD, Keiper MC, Olrich TW. Virtual(ly) athletes: where esports fit within the definition of «sport». 2017;69:1-18

28. Jonasson K, Thiborg J. Electronic sport and its impact on future sport. Sport in society cultures, commerce, media, politics. 2010;13(2):287-99. doi.org/10.1080/17430430903522996.

\section{LITERATURE}

1. Boldyreva SP, Grishachev AS. E-sports Vestnik nauchnykh konferentsiy. 2017;3-6(19):24 5.

2. Buyanova AV, Kozilina VV. E-sports: history of development, modern state and develop ment prospects. Sotsialno-politicheskiye nauki. 2017:5:77-80

3. Bykov NN. E-sports as a means for improving efficiency of student professional preparation. Intellectual resources to regional development. 2020;2:123-6

4. Zavalniuk OV. Sports phenomenon: from philosophical theory to modern practic. Kyiv: NPU im. M. P. Drahomanov; 2017. 384 p.

5. Ismailov AA. E-sports as a social phenomenon. International Journal of Humanities and Natural Sciences. 2019;7-1:40-2

6. Imas IV, Michuda IP. Development trends of physical culture and sport in modern market conditions. Teoriia i metodyka fizvykhovannia i sportu. 2015:2:142-9.

7. Kazakova OA, Kozma NA. E-sports is a sport of future. Olymplus. 2016;1(2):29-31.

8. Korchemnaya NV. Preventing professiona diseases of esports athletes. E-sports: issues and prospects. Materialy III Vseros. nauchno-prakt. konf., December 16-20, 2014. 2014;16-21.

9. Kravchenko VI. Features of "informative" person transformation. Vestnik LSU im. A. S. Pushkin. 2012;1:114

10. Kushnareva IA, Strichko AV. E-sports. New science: experience, traditions, innovations. 2015:1:31-2

11. Mayorova LV. To the issue of strategic thinking development in young athletes through computer games. E-sports: issues and prospects Materialy III Vseros. nauchno-prakt. konf., December 16-20, 2014. 2014;22-6.

12. Meshcheryakov AV, Novoselov MA Skarzhinskaya EN. Regulatory system activity in computer games. E-sports: issues and prospects. Materialy III Vseros. nauchno-prakt. konf., December 16-20, 2014. 2014;22-6.

13. Mironov IV. E-sports as (re)socialization tool. Zhurnal BSU. Filosofiya. Psikhologiya 2019:2:62-7.

14. Nazarova EV. E-sports and business: review of growth and cooperation points. E-sports: issues and prospects. Materialy III Vseros. nauchno-prakt. konf., December 16-20, 2014. 2014;22 6.

15. Pankina VV, Khadieva RT. E-sports as the phenomenon of the XXI century. Physical culture. Sport. Tourism. Motor activity. 2016;1(3):34-8.
16. Predovskaya MM Tebyakina EE E-sports - sports reality of a new world. Materialy nauchno-prakt. konf. NSUPCSH im. P. F. Lesgaft. 2019;162-5.

17. Semibratova AV. E-sports as a part of adaptive physical culture. State and development prospects of physical culture, sport and adaptive physical culture. Sb. Statey po materialam Vseros. Studencheskoy nauchno-prakt. konf., April 18 2019. 2019;79-82.

18. Skarzhinskaya EN, Novoselov MA Surkont KV. E-sports - a kind of sport? E-sports: issues and prospects. Materialy III Vseros. nauchno-prakt. konf., December 16-20, 2014. 2014;69-74.

19. Solovyeva EV. School children dependence on computer games. E-sports: issues and prospects. Materialy III Vseros. nauchno-prakt. konf., December 16-20, 2014. 2014;80-3.

20. Treshcheva EE, chedzhemov GA. Postmodern epoch. Society of virtual reality. Nauka XXI veka: aktualnyye napravleniya razvitiya 2017:1(1):122-5

21. Cottrell C, Nicholas Mcmillen N, Harris BS Sport psychology in a virtual world: Considerations for practitioners working in esports. Journal of Sport Psychology in Action. 2019;10(2):73-81. doi.org/10.1080/21520704.2018.1518280

22. Hilvoorde IV, Pot N. Sport and Play in a Digital World Embodiment and fundamental motor skills in esports. Sport, Ethics and Philosophy 2016;10(1):1-14.

23. Llorens MR. Esport gaming: the rise of a new sports practice. Sport, ethics and philosophy 2017; 11(4):464-7. doi.org/10.1080/17511321.20 17.1318947.

24. Miah A. The cybersport nexus, in Billings, A. \& Hardin, M. The Routledge Handbook of Sport and New Media, Oxon \& New York, Routledge. 2014;76-86.

25. Pedraza-Ramirez I, Musculus L, Raab M Laborde S. Setting the scientific stage for esports psychology: a systematic review. International Review of Sport and Exercise Psychology. 2020;13(1):319-52. doi.org/10.1080/175098 4X.2020.1723122.

26. Seo Y. Electronic sports: a new marketing landscape of the experience economy. Journal of marketing management. 2013;29(13-14):1542-60.

27. Jenny SE, Manning RD, Keiper MC, Olrich TW. Virtual(ly) athletes: where esports fit within the definition of «sport». 2017;69:1-18

28. Jonasson K, Thiborg J. Electronic sport and its impact on future sport. Sport in society cultures commerce, media, politics. 2010;13(2):287-99 doi.org/10.1080/17430430903522996.

Надійшла 16.12.2020

\section{ІНФОРМАЦІЯ ПРО АВТОРА}

Імас Євгеній Вікторович https://orcid.org/0000-0003-0641-678X, e.imas@ukr.net

Національний університет фізичного виховання і спорту України,

03150, Київ, вул. Фізкультури, 1

\section{INFORMATION ABOUT THE AUTHOR}

Imas Yevgeniy https://orcid.org/0000-0003-0641-678X, e.imas@ukr.net

National University of Ukraine on Physical Education and Sport,

03150, Kyiv, Fizkul'tury str., 1 